\title{
Should a family history of papillary thyroid carcinoma indicate more aggressive therapy in patients with this tumor?
}

\author{
História familiar de carcinoma papilífero de tireoide deve indicar \\ terapia mais agressiva em pacientes com este fumor?
}

Pedro Weslley Rosario ${ }^{1,2}$, Maria Regina Calsolari²

1 Postgraduation Program, Santa Casa de Belo Horizonte, MG, Brazil ${ }^{2}$ Endocrinology Service, Santa Casa de Belo Horizonte, MG, Brazil

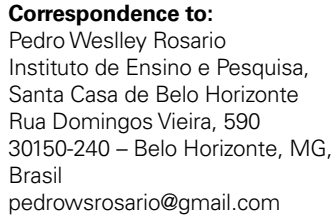

\begin{abstract}
Objective: To determine whether the currently recommended therapy for papillary thyroid carcinoma (PTC) that show no classical factors indicating a poor prognosis is also effective in cases with a family history of this tumor. Subjects and methods: Forty-two patients were studied; 10 were submitted to lobectomy and 32 to total thyroidectomy, including 23 without lymph node dissection and 9 with lymph node dissection. None of the patients received radioiodine or was maintained under TSH suppression. Results: No case of recurrence was detected by imaging methods and there was no increase in thyroglobulin or antithyroglobulin antibodies during follow-up (24 to 72 months). Conclusion: The treatment usually recommended for patients with PTC does not need to be modified in the presence of a family history of this tumor if no factors indicating a poor prognosis are present (tumor $\leq 2 \mathrm{~cm}$, non-aggressive histology, no extensive extrathyroid invasion or important lymph node involvement, complete tumor resection, no evidence of persistent disease after surgery). Arq Bras Endocrinol Metab. 2014;58(8):812-6
\end{abstract}

\section{Keywords}

Papillary thyroid carcinoma; familial history; radioiodine; TSH supression; elective lymph node dissection

\section{RESUMO}

Objetivo: Avaliar se a terapia atualmente recomendada para o carcinoma papilífero de tireoide (CPT) sem fatores clássicos de pior prognóstico é efetiva também nos casos em que existe história familiar deste tumor. Sujeitos e métodos: Foram avaliados 42 pacientes; dez foram tratados com lobectomia e 32 com tireoidectomia total, sendo 23 sem dissecção de linfonodos e 9 com dissecção linfonodal. Nenhum paciente recebeu radioiodo ou foi mantido com TSH suprimido. Resultados: Nenhuma recidiva nos métodos de imagem foi observada, nem incremento da tireoglobulina ou anticorpos antitireoglobulina durante o seguimento (24 a 72 meses). Conclusão: Em pacientes com CPT, sem fatores de pior prognóstico (tumor $\leq 2 \mathrm{~cm}$, histologia não agressiva, sem invasão extratireoidiana extensa ou acometimento linfonodal importante, ressecção tumoral completa, sem indícios de doença persistente após a cirurgia), o tratamento usualmente recomendado não precisa ser modificado quando há história familiar desse tumor. Arq Bras Endocrinol Metab. 2014;58(8):812-6

Descritores

Carcinoma papilífero de tireoide; história familiar; radioiodo; supressão do TSH; dissecção linfonodal eletiva 


\section{INTRODUCTION}

$\mathrm{T}$ raditionally, the definition of recurrence risk in patients with papillary thyroid carcinoma (PTC) is based on histological data (size, number of foci and subtype of the tumor; extrathyroid and vascular invasion; metastases) and tumor resection (1-4). Some studies suggested the diagnosis of PTC in a relative(s) to be a risk factor for recurrence (5-10). Since this information has not been included in risk stratification (1-4) and one of the main objectives of this stratification is to guide therapy, it is important to know whether the diagnosis of PTC in a first-degree relative would influence (or modify) the current therapeutic recommendations.

With respect to treatment of PTC, there is agreement that total thyroidectomy is the most adequate initial procedure (1-4). In the presence of clinically apparent metastases $(\mathrm{cNl})$, therapeutic lymph node dissection is also consensus (1-4). Similarly, treatment or adjuvant therapy with ${ }^{131} \mathrm{I}$ and TSH suppression have been recommended for patients with incomplete tumor resection, persistent disease, or high risk for recurrence (1-4). Obviously, a family history does not modify these managements. Therefore, the controversy regarding the possible importance of family history for therapy lies in subjects who are at low risk of recurrence and for whom elective cervical lymph node dissection, ablation with ${ }^{131} \mathrm{I}$ or TSH suppression have not been recommended (1-4).

The objective of this prospective study was to determine whether the currently recommended therapy for patients with PTC who show no classical factors indicating a poor prognosis (no cervical lymph node dissection, ablation with ${ }^{131}$ I or TSH suppression) is also effective when they have a family history of this tumor.

\section{SUBJECTS AND METHODS}

First, 723 siblings of 447 patients with PTC (a single case in the family until that time) were screened by ultrasonography (US) (11). This screening resulted in the diagnosis of PTC in one additional relative in 21 families and in two additional relatives in 11 families (11). These 43 cases detected by US screening were included in this prospective study. Family syndromes associated with PTC such as familial adenomatous polyposis, Gardner's syndrome, Cowden disease, Werner's syndrome, and Carney's complex were excluded in all patients.

The extent of surgery was defined according to the criteria shown in table 1 . Ten patients were submit- ted to lobectomy, 23 to total thyroidectomy without lymph node dissection, and 10 to total thyroidectomy and lymph node dissection.

Table 1. Criteria for definition of the extent of surgery

\begin{tabular}{lccc}
\hline Cytology & $\begin{array}{c}\text { Nodular } \\
\text { disease }\end{array}$ & $\begin{array}{c}\text { Preoperative } \\
\text { US and } \\
\text { perioperative } \\
\text { evaluation }\end{array}$ & Extent of surgery \\
\hline $\begin{array}{l}\text { Suspicious or } \\
\text { malignant }\end{array}$ & $\begin{array}{c}\text { Uni- or } \\
\text { bilateral }\end{array}$ & $\begin{array}{c}\text { Negative } \\
\text { Suspicious lymph } \\
\text { nodes }\end{array}$ & $\begin{array}{c}\text { Total thyroidectomy } \\
\text { Total thyroidectomy and } \\
\text { therapeutic lymph node } \\
\text { dissection }\end{array}$ \\
$\begin{array}{l}\text { Indeterminate or } \\
\text { nondiagnostic }\end{array}$ & $\begin{array}{c}\text { Unilateral } \\
\text { Bilateral }\end{array}$ & Negative & Negative \\
Uni- or & Suspicious lymph & Total thyroidectomy \\
bilateral & nodes & $\begin{array}{c}\text { Total thyroidectomy and } \\
\text { therapeutic lymph node } \\
\text { dissection }\end{array}$ \\
\hline
\end{tabular}

In patients undergoing lobectomy, measurement of serum thyroglobulin ( $\mathrm{Tg}$ ) and anti-Tg antibodies $(\mathrm{TgAb})$ during therapy with levothyroxine (L-T4) and neck US were performed 6 months after surgery and then annually.

In patients treated with total thyroidectomy, ablation with ${ }^{131}$ I was indicated according to the algorithm shown in figure 1 . Only one patient received radioiodine due to the presence of 5 metastatic lymph nodes. This patient was excluded from the study. One year after total thyroidectomy, the patients were evaluated according to the algorithm shown in figure 2. After, the patients were followed up by serum measurement of basal $\mathrm{Tg}$ and $\mathrm{TgAb}$ and annual US.

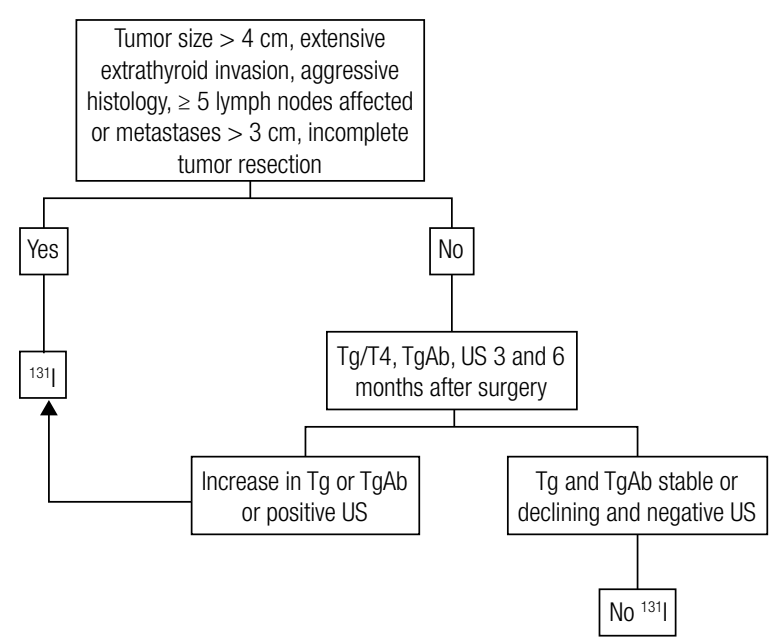

LN: lymph nodes; Tg/T4: thyroglobulin measured during levothyroxine therapy; TgAb: anti-thyroglobulin antibodies; US: ultrasonography.

Figure 1. Criteria for indication of ${ }^{131}$ I after total thyroidectomy. 


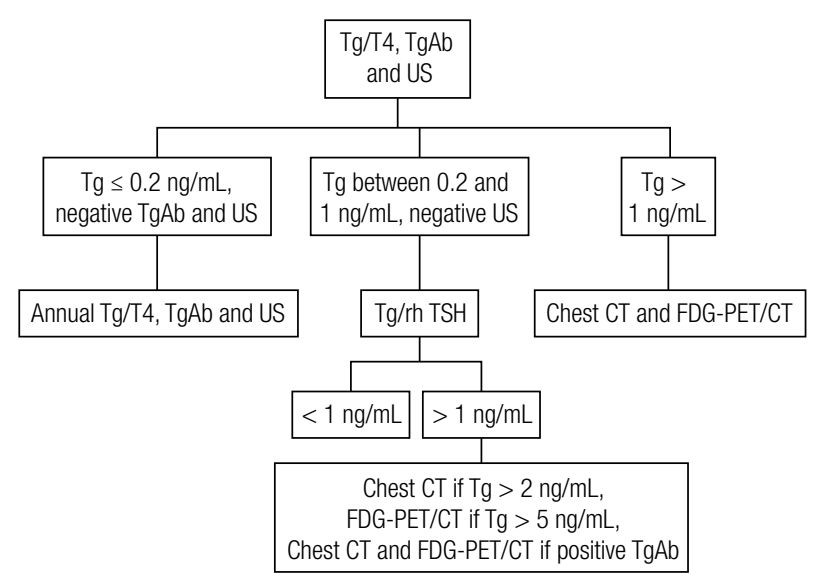

$\mathrm{Tg} / \mathrm{T}$ : thyroglobulin measured during levothyroxine therapy; TgAb: anti-thyroglobulin antibodies; rhTSH: recombinant human TSH; US: ultrasonography; CT: computed tomography.

Figure 2. Assessment 1 year after total thyroidectomy.

All patients were maintained on an L-T4 dose sufficient to obtain TSH levels of 0.3 to $2 \mathrm{mIU} / \mathrm{L}$.

The study was approved by the Research Ethics Committee of our Institution.

Tg was measured by a chemiluminescent assay (Access Thyroglobulin Assay, Beckman Coulter, Fullerton, $\mathrm{CA}$ ) with a functional sensitivity of $0.1 \mathrm{ng} / \mathrm{mL}$. TgAb was measured by a chemiluminescent assay [Immulite 2000, Diagnostic Products Corporation, Los Angeles, CA (reference value of up to $40 \mathrm{IU} / \mathrm{mL}$ ) or ARCHITET Anti-Tg, Abbott Laboratories, IL (reference value of up to $4.11 \mathrm{IU} / \mathrm{mL}$ )].

US was performed with a linear multifrequency 14 $\mathrm{MHz}$ transducer for morphological analysis and for power Doppler evaluation. US was defined as negative when no suspicious lesions were detected $(12,13)$ or, in the presence of these lesions, when cytology and Tg measurement in the needle washout fluid obtained by USguided fine-needle aspiration were negative. Chest and mediastinal computed tomography (CT) was performed on 5-mm sequential sections. FDG-PET/CT was carried out after stimulation with recombinant human TSH.

\section{RESULTS}

Thirty of the 42 patients included were women and 12 were men. Patient age ranged from 14 to 67 years (mean 35 years). TNM stage and risk stratification are shown in table 2 . With respect to tumor size $>1 \mathrm{~cm}$, multicentricity, extrathyroid invasion and clinically apparent lymph node metastases $(\mathrm{cNl}), 30$ patients presented at least one finding and 14 had at least two of these findings.
The time of follow-up ranged from 24 to 72 months (median 50 months). The imaging methods did not detect apparent metastases in any of the patients during follow-up after surgery. The behavior of tumor markers ( $\mathrm{Tg}$ and $\mathrm{TgAb}$ ) during follow-up are shown in table 3.

Table 2. TNM stage and risk stratification

\begin{tabular}{ll}
\hline TNM stage & T1aNxM0 $(n=20)$ \\
& T1aNOM0 $(n=1)$ \\
& T1bNxM0 $(n=6)$ \\
& T3NxM0 $(n=6)$ \\
& T1aN1a $(n=4)$ \\
& T1bN1a $(n=2)$ \\
& T3N1a $(n=3)$ \\
& Low risk $(n=27)$ \\
American Thyroid Association (1) & Intermediate risk $(n=15)$ \\
Brazilian Society of Endocrinology and & Low risk $(n=38)$ \\
Metabolism (4) & Intermediate risk $(n=4)$ \\
Latin American Thyroid Society (2) & Low risk $(n=27)$ \\
& Intermediate risk $(n=15)$ \\
European Society for Medical & Low risk $(n=21)$ \\
Oncology (3) & Intermediate risk $(n=12)$ \\
& High risk $(n=9)$ \\
\hline
\end{tabular}

Table 3. Behavior of tumor markers (Tg and TgAb) during follow-up

\begin{tabular}{|c|c|c|}
\hline Inicial surgery & $\begin{array}{l}\text { Results of last } \\
\text { assessment }\end{array}$ & $\begin{array}{l}\text { Behavior of tumor } \\
\text { markers }\end{array}$ \\
\hline \multirow[t]{2}{*}{ Lobectomy $(n=10)$} & $\begin{array}{l}\text { Negative } \operatorname{TgAb} \text { and } \\
\text { basal } \operatorname{Tg}>1 \mathrm{ng} / \mathrm{mL} \\
(\mathrm{n}=8)\end{array}$ & $\begin{array}{l}\text { Tg reduction }>30 \% \\
\text { compared to } \operatorname{Tg} 6 \text { months } \\
\text { after surgery }\end{array}$ \\
\hline & $\begin{array}{l}\text { Positive } \operatorname{TgAb} \text { and } \\
\text { undetectable basal } \\
\operatorname{Tg}(n=2)\end{array}$ & $\begin{array}{l}\text { TgAb reduction }>50 \% \\
\text { compared to the titers found } \\
6 \text { months after surgery }\end{array}$ \\
\hline \multirow{3}{*}{$\begin{array}{l}\text { Total thyroidectomy } \\
\text { with or without } \\
\text { lymph node } \\
\text { dissection ( } n=32)\end{array}$} & $\begin{array}{l}\text { Negative } \operatorname{TgAb} \text { and } \\
\text { basal } \operatorname{Tg}<0.2 \mathrm{ng} / \mathrm{mL} \\
(\mathrm{n}=18)\end{array}$ & $\begin{array}{l}\text { Initial stimulated } \mathrm{Tg} \leq 1 \mathrm{ng} / \mathrm{mL} \\
(\mathrm{n}=8) \rightarrow \text { basal } \mathrm{Tg}<0.5 \\
\mathrm{ng} / \mathrm{mL} \text { and stable or } \\
\text { declining compared to } \mathrm{Tg} 1 \\
\text { year after surgery }\end{array}$ \\
\hline & $\begin{array}{l}\text { Negative } \mathrm{TgAb} \text { and } \\
\text { basal } \mathrm{Tg}>0.2 \mathrm{ng} / \mathrm{mL} \\
(\mathrm{n}=11)\end{array}$ & $\begin{array}{l}\text { Initial stimulated } \mathrm{Tg}>2 \mathrm{ng} / \mathrm{mL} \\
(\mathrm{n}=3) \rightarrow \operatorname{Tg} \text { declining } \\
\text { compared to Tg obtained } 1 \\
\text { year after surgery. Last } \\
\text { stimulated } \mathrm{Tg} \text { was }<2 \mathrm{ng} / \mathrm{mL} \\
\text { in } 2 \text { patients and } 3.1 \mathrm{ng} / \mathrm{mL} \\
\text { in the other }\end{array}$ \\
\hline & $\begin{array}{l}\text { Positive TgAb and } \\
\text { undetectable basal Tg } \\
(n=3)\end{array}$ & $\begin{array}{l}\text { TgAb reduction }>50 \%(n= \\
\text { 2) or stable } \operatorname{TgAb}\left(n=1^{b}\right) \\
\text { compared to the titers found } \\
1 \text { year after surgery }\end{array}$ \\
\hline
\end{tabular}

a US, CT and FDG-PET/CT, repeated in the last assessment, did not reveal disease.

${ }^{\mathrm{b}}$ US and CT repeated at the end of the study were negative for metastases. 


\section{DISCUSSION}

Some studies have shown a higher risk of recurrence in the case of family aggregation of PTC compared to sporadic PTC (5-10), but this observation is not confirmed in all studies (14-20). There is even greater controversy to know whether the possible increased risk is due to the more aggressive initial presentation or whether a family history itself is an independent risk factor for recurrence (14). This information is important to define whether patients with a family history of PTC require more aggressive treatment than the one usually recommended, as proposed by some authors $(6,21,22)$. More aggressive therapy (including ${ }^{131} \mathrm{I}$ and TSH suppression) is already recommended for patients with incomplete tumor resection, persistent disease immediately after surgery or high risk of recurrence, irrespective of family history (1-4). Therefore, the controversy is restricted to cases that show no classical factors indicating a poor prognosis, which was the objective of this prospective study. The present results suggest that the common recommendation of total thyroidectomy without elective lymph node dissection, ablation with ${ }^{131}$ I or TSH suppression seems to be sufficient in these patients, even in the presence of a family history of PTC (1-4). Based on the characteristics of the patients included in the study, this conclusion only applies to those presenting the criteria shown in table 4 , which were observed in all of them.

Table 4. Prognostic factors observed in all patients included in the study Tumor $\leq 2 \mathrm{~cm}$

Non-aggressive histology

Absence of extensive extrathyroid invasion

$<5$ lymph nodes affected and no metastases $\geq 3 \mathrm{~cm}$

Apparently complete tumor resection

No signs of persistent disease immediately after surgery

Another doubt is related to the question whether a poor prognosis of PTC exists only when three or more relatives are affected $(5,7)$. Studies have shown a more aggressive behavior of the tumor even when there are only two relatives affected (6-10). In the present series, no recurrence was observed even in patients of families with three affected relatives.

The present study has some limitations. The first is the small number of patients included, but the lack of recurrence minimizes the relevance of sample size. The second limitation is the time of follow-up; however, it is known that approximately $80 \%$ of recurrences occur in the first 5 years of follow-up (23). In addition, the results found [US persistently showing no anomalies associated with basal $\mathrm{Tg} \leq 0.2 \mathrm{ng} / \mathrm{mL}$ (24) or stimulated $\mathrm{Tg}<1-2 \mathrm{ng} / \mathrm{mL}$ (24); stable or declining $\mathrm{Tg}$ (25-27), or $\mathrm{TgAb}$ reduction $>50 \%(28)$ ] make the occurrence of long-term recurrence rates that would modify the conclusion of the study unlikely. On the other hand, strengths of the study are its prospective design using pre-defined and uniform initial therapy and follow-up; inclusion of exactly the group of patients for which controversy exists; the therapy performed (no elective lymph node dissection, ablation with ${ }^{131}$ I or TSH suppression); and even the surprising result (absence of apparent recurrence). Specifically in this subgroup of patients (PTC $\leq 2 \mathrm{~cm}$ and no unfavorable risk factors), there is low risk of structural disease recurrence after less extensive surgery and without radioiodine (29). In fact, we reviewed the data of 58 patients seen at our institution, who were similar to the present patients (nonaggressive PTC $\leq 2 \mathrm{~cm}$ ) and were submitted to the same therapy and follow-up, but who had sporadic tumors $(30,31)$. None case of recurrence was also detected in this group $(30,31)$.

In conclusion, the treatment usually recommended for patients with PTC who show no unfavorable risk factors (1-4) does not need to be modified in the presence of a family history of this tumor. Studies involving a larger number of patients are needed to confirm this conclusion.

Disclosure: no potential conflict of interest relevant to this article was reported.

\section{REFERENCES}

1. Cooper DS, Doherty GM, Haugen BR, Kloos RT, Lee SL, Mandel SJ, et al. Revised American Thyroid Association management guidelines for patients with thyroid nodules and differentiated thyroid cancer. Thyroid. 2009;19(11):1167-214.

2. Pitoia F, Ward L, Wohllk N, Friguglietti C, Tomimori E, Gauna A, et al. Recommendations of the Latin American Thyroid Society on diagnosis and management of differentiated thyroid cancer. Arq Bras Endocrinol Metabol. 2009;53(7):884-7.

3. Pacini F, Castagna MG, Brilli L, Pentheroudakis G. Thyroid cancer: ESMO Clinical Practice Guidelines for diagnosis, treatment and follow-up. Ann Oncol. 2012;23(suppl 7):110-9.

4. Rosário PW, Ward LS, Carvalho GA, Graf H, Maciel RM, Maciel LM, et al. Thyroid nodules and differentiated thyroid cancer: update on the Brazilian consensus. Arq Bras Endocrinol Metabol. 2013;57(4):240-64.

5. Alsanea O, Wada N, Ain K, Wong M, Taylor K, Ituarte PH, et al. Is familial non-medullary thyroid carcinoma more aggressive than sporadic thyroid cancer? A multicenter series. Surgery. 2000;128(6):1043-51. 
6. Uchino S, Noguchi S, Kawamoto H, Yamashita H, Watanabe S, Yamashita $\mathrm{H}$, et al. Familial nonmedullary thyroid carcinoma characterized by multifocality and a high recurrence rate in a large study population. World J Surg. 2002;26(8):897-902.

7. Triponez F, Wong M, Sturgeon C, Caron N, Ginzinger DG, Segal $\mathrm{MR}$, et al. Does familial non-medullary thyroid cancer adversely affect survival? World J Surg. 2006;30(5):787-93.

8. McDonaldTJ, Driedger AA, Garcia BM, Van Uum SH, Rachinsky I, Chevendra V, et al. Familial papillary thyroid carcinoma: a retrospective analysis. J Oncol. 2011;2011:948786.

9. Mazeh H, Benavidez J, Poehls JL, Youngwirth L, Chen H, Sippel RS. In patients with thyroid cancer of follicular cell origin, a family history of nonmedullary thyroid cancer in one first-degree relative is associated with more aggressive disease. Thyroid. 2012;22(1):3-8.

10. Lee YM, Yoon JH, Yi O, Sung TY, Chung KW, Kim WB, et al. Familial history of non-medullary thyroid cancer is an independent prognostic factor for tumor recurrence in younger patients with conventional papillary thyroid carcinoma. J Surg Oncol. 2014;109(2):168-73.

11. Rosario PW, Mineiro Filho AF, Prates BS, Silva LC, Lacerda RX, Calsolari MR. Ultrasonographic screening for thyroid cancer in siblings of patients with apparently sporadic papillary carcinoma. Thyroid. 2012;22(8):805-8.

12. Rosario PW, Faria S, Bicalho L, Gatti Alves MF, Borges MAR, Purisch $\mathrm{S}$, et al. Ultrasonographic differentiation between metastatic and benign lymph nodes in patients with papillary thyroid carcinoma. J Ultrasound Med. 2005;24(10):1385-9.

13. Rosario PW, Tavares WC, Borges MAR, Santos JBN, Calsolari MR. Ultrasonographic differentiation of cervical lymph nodes in patients with papillary thyroid carcinoma after thyroidectomy and radioiodine ablation: a prospective study. Endocr Pract. 2014;20(4):293-8.

14. Loh KC. Familial nonmedullary thyroid carcinoma: a meta-review of case series. Thyroid 1997;7(1):107-13.

15. Maxwell EL, Hall FT, Freeman JL. Familial non-medullary thyroid cancer: a matched-case control study. Laryngoscope. 2004;114(12):2182-6.

16. Robenshtok E,Tzvetov G, Grozinsky-Glasberg S, Shraga-Slutzy I, Weinstein R, Lazar $L$, et al. Clinical characteristics and outcome of familial nonmedullary thyroid cancer: a retrospective controlled study. Thyroid. 2011;21(1):43-8.

17. Moses W, Weng J, Kebebew E. Prevalence, clinicopathologic features, and somatic genetic mutation profile in familial versus sporadic nonmedullary thyroid cancer. Thyroid. 2011;21(4):367-71.

18. Pitoia F, Cross G, Salvai ME, Abelleira E, Niepomniszcze H. Patients with familial non-medullary thyroid cancer have an outcome similar to that of patients with sporadic papillary thyroid tumors. Arq Bras Endocrinol Metabol. 2011;55(3):219-23.

19. Pinto A, Silva G, Henrique R, Menezes F, Teixeira M, Leite V, et al. Familial versus sporadic papillary thyroid carcinoma: a matched- case comparative study showing similiar clinical/prognostic behavior. Eur J Endocrinol. 2013;170(2):321-7.

20. Lee J, SongY, Soh EY. Central lymph node metastasis is an important prognostic factor in patients with papillary thyroid microcarcinoma. J Korean Med Sci. 2014;29(1):48-52.

21. Sippel RS, Caron NR, Clark OH. An evidence-based approach to familial nonmedullary thyroid cancer: screening, clinical management, and follow-up. World J Surg. 2007;31(5):924-33.

22. Mazeh $H$, Sippel RS. Familial nonmedullary thyroid carcinoma. Thyroid. 2013;23(9):1049-56.

23. Durante C, Montesano T, Torlontano M, Attard M, Monzani F, Tumino S, et al. Papillary thyroid cancer: time course of recurrences during postsurgery surveillance. J Clin Endocrinol Metab. 2013;98(2):636-42.

24. Brassard M, Borget I, Edet-Sanson A, Giraudet AL, Mundler O, Toubeau $M$, et al. Long-term follow-up of patients with papillary and follicular thyroid cancer: a prospective study on 715 patients. $\mathrm{J}$ Clin Endocrinol Metab. 2011;96(5):1352-9.

25. Baudin E, Do Cao C, Cailleux AF, Leboulleux S, Travagli JP, Schlumberger $\mathrm{M}$. Positive predictive value of serum thyroglobulin levels, measured during the first year of follow-up after thyroid hormone withdrawal, in thyroid cancer patients. J Clin Endocrinol Metab. 2003;88(3):1107-11.

26. Valadão MM, Rosário PW, Borges MA, Costa GB, Rezende LL, Padrao EL, et al. Positive predictive value of detectable stimulated Tg during the first year after therapy of thyroid cancer and the value of comparison with Tg-ablation and Tg measured after 24 months. Thyroid. 2006;16(11):1145-9.

27. Wong $H$, Wong KP, Yau T, Tang V, Leung $R$, Chiu J, et al. Is there a role for unstimulated thyroglobulin velocity in predicting recurrence in papillary thyroid carcinoma patients with detectable thyroglobulin after radioiodine ablation? Ann Surg Oncol. 2012;19(11):3479-85.

28. Kim WG, Yoon JH, Kim WB, Kim TY, Kim EY, Kim JM, et al. Change of serum antithyroglobulin antibody levels is useful for prediction of clinical recurrence in thyroglobulin-negative patients with differentiated thyroid carcinoma. J Clin Endocrinol Metab. 2008;93(12):4683-9.

29. Vaisman F, Shaha A, Fish S, Michael Tuttle R. Initial therapy with either thyroid lobectomy or total thyroidectomy without radioactive iodine remnant ablation is associated with very low rates of structural disease recurrence in properly selected patients with differentiated thyroid cancer. Clin Endocrinol (Oxf). $2011 ; 75(1): 112-9$.

30. Rosário PW, Fagundes TA, Purisch S. Treatment of papillary microcarcinoma of the thyroid. Arq Bras Endocrinol Metabol. 2004;48(6):855-60.

31. Rosário PW, Borges MA, Valadão MM, Vasconcelos FP, Rezende LL, Padrão EL, et al. Is adjuvant therapy useful in patients with papillary carcinoma smaller than $2 \mathrm{~cm}$ ? Thyroid. 2007;17(12):1225-8. 